\title{
Onomatological analysis of the technonyms in the sphere of energetics (based on the Russian, English and Chinese languages)
}

\author{
Tatiana S. Plutalova ${ }^{1, *}$, Juri V. Kobenko ${ }^{2}$, and Elena S. Riabova ${ }^{3}$ \\ ${ }^{1}$ National Research Tomsk Polytechnic University, 634050 Tomsk, Russia \\ ${ }^{2}$ National Research Tomsk State University, 634050 Tomsk, Russia \\ ${ }^{3}$ Samara University, 443086 Samara, Russia
}

\begin{abstract}
The article deals with the results of the onomatological analysis of the names of renewable energy facilities in the Russian, English and Chinese languages. The relevance of the study is determined by the trends in the development of these languages and their onomasiological foundation, which require focused attention of linguists in the context of an avalanche-type enlargement of terminological spheres. The results of the research can be useful for a wide range of specialists in humanities, including interpreters working with terminological thesauri in the sphere of renewable and resource energy.
\end{abstract}

\section{Introduction}

The modern world is in the state of a continuous development: the emergence and spread of various technologies in the industrial sectors cause a continuous creation of new technological objects. In connection with the current ecological situation on the planet, renewable energy is becoming an increasingly important alternative to raw energy, replacing fossil energy sources with renewable ones. Thus, the number of new energy facilities is constantly growing all over the world, each of them is called in a certain way that is typical for the nominative traditions of a particular language. Interpreters in the field of professional communication have to adequately and equivalently interpret national technonyms in the context of intercultural transfer, which requires a high level of proficiency in terminological thesauri, especially in such a demanded branch of the economics as renewable energy. The creation of the thesaurus needs a logical, motivated, consistent classification of the technonyms, which will allow us to trace certain patterns in the name of objects in the field of renewable energy in the Chinese, English and Russian languages [1]. This article presents the results of the onomatological analysis (the term of A.K. Matveev [4]), the aim of which is to identify the peculiarities of the alternative energy objects (technonyms) naming in the English, Russian and Chinese languages. Technonyms

\footnotetext{
* Corresponding author: plutalova tat@mail.ru
} 
in onomastics include the names of technology and electronics, and in the context of our research the names of energy objects are also included [2]. Being a part of a single energy sector, the names "Sayano-Shushenskaya HPP" and "Baikhetan Daba 白鹤滩大坝" (translated as: "White Crane Coast" Dam), "Churchill Waterfall" look completely different and incomparable, and they represent the multi-structural names of the different group languages but not single-word onyms for which the word-formation analysis would be applicable [3]. In this regard, it seems relevant to carry out an onomatological analysis of Russian, Chinese and English nominations in order to identify onomastic features of technonyms naming in the field of renewable energy in languages mentioned above.

The object of onomatological analysis was onomastic segments of technonyms in the field of renewable energy in the English, Russian and Chinese languages. While compiling the trilingual corpus of nominations with the help of a continuous sample, 124 units were singled out, that contained 23 nominations in Chinese, 42 in English, 59 in Russian. Technonyms in the field of energetics in different languages as well as onomastic vocabulary in general are strikingly different: in Chinese, for example, technonyms of toponymic character prevail (toponym is the name of one's own part of space [5]), for example: HPP “Three Gorges 三峡” is the largest hydroelectric power station in the world, named after the territory on which it is located, the name derives from the name of the region (oronim - the relief notion), and in the English language there is a tendency to form technonyms of anthroponymic character (in the honor of outstanding personalities, for example: HPP “W. A. C. Bennett Dam” named after British Columbia's 25th Canadian Prime Minister, William Bennett).

\section{The results of the onomatological analysis of the technonyms}

It should be emphasized that very often the aim of onomatological analysis is the identification of subclasses of onyms that form a definite onomastic segment of the vocabulary [6]. Analysis data of the technonyms in the English language are presented in Table 1

Table 1. English technonyms in the sphere of energetics.

\begin{tabular}{|c|c|c|}
\hline \multicolumn{2}{|c|}{ subclasses of technonyms } & naming units \\
\hline \multirow{4}{*}{ toponyms } & hydronym & Manapouri Power Station \\
\hline & hydronym & Tumut Hydroelectric Power Station \\
\hline & hydronym & Gordon Dam \\
\hline & hydronym & Murray Hydroelectric Power Station \\
\hline \multirow{5}{*}{ toponyms } & oronym & Snowy Mountains Scheme \\
\hline & oronym & Kárahnjúkar \\
\hline & oronym & Grand Coulee Dam \\
\hline & oronym & Mojave \\
\hline & oronym & Solar Ranch \\
\hline \multirow{3}{*}{ toponyms } & oikonym & Guthega \\
\hline & oikonym & Mica Dam \\
\hline & oikonym & Revelstoke Dam \\
\hline \multirow{6}{*}{\multicolumn{2}{|c|}{ anthroponyms }} & Robert-Bourassa generating station \\
\hline & & Churchill Falls \\
\hline & & W. A. C. Bennett Dam \\
\hline & & Daniel-Johnson Dam \\
\hline & & Chief Joseph Dam \\
\hline & & Hoover Dam \\
\hline
\end{tabular}




\begin{tabular}{|c|c|}
\cline { 2 - 2 } & Robert Moses Niagara Power Plant \\
\cline { 2 - 2 } & Solana \\
\cline { 2 - 2 } & Clyde Dam \\
\hline ethnonym & Ivanpah \\
\hline astronym & Star \\
\hline phytonym & Mesquite \\
\hline
\end{tabular}

It is important to note that the technonyms naming of the English language has a tendency to use the names of famous personalities in the technonyms formation. Nominators often refer to the image of outstanding public figures and use the idea of these people as charismatic leaders, emphasizing the unique character of the object.

Most of the technonyms in the Chinese language are represented by toponyms (technonyms that include the geographical name of the territorial object), oronyms in particular (technonyms that include the name of any crustal relief object) and oikonyms (nominations that include the name of the locality). The analysis of the Chinese onomastic technology segment in the energetics sector is presented in Table 2.

Table 2. Chinese technonyms in the sphere of energetics.

\begin{tabular}{|c|c|c|}
\hline \multicolumn{2}{|c|}{ subclasses of technonyms } & naming units \\
\hline \multirow{7}{*}{ toponyms } & oronym & HPP “Three Gorges” 三峡大坝 \\
\cline { 2 - 3 } & oikonym & HPP Silodu 奚落度 \\
\cline { 2 - 3 } & oikonym & HPP Jinping 锦屏一级水电站 \\
\cline { 2 - 3 } & oikonym & $\begin{array}{c}\text { HPP Huyaosia “虎跳峡大坝”(Tiger } \\
\text { Leaping Gorge }\end{array}$ \\
\cline { 2 - 3 } & oikonym & Liujiaxia Dam 刘家峡大坝 \\
\cline { 2 - 3 } & oikonym & Dabancheng Wind Farm 达坂城区 \\
\cline { 2 - 3 } & oikonym & $\begin{array}{c}\text { Gansu Wind Farm (also called Jiuquan } \\
\text { Wind Power Base) 酒泉市 }\end{array}$ \\
\cline { 2 - 3 } & oikonym & Longyangxia Dam 龙羊峡水库 \\
\hline
\end{tabular}

Onomatological analysis allows us to conclude that the names of the Chinese language are most marked by poetry and metaphoricity, which is easily explained by the cultural pecularities of the country, characterized by aesthetic onomastic space. According to the definition given by T.V. Shmelyova in the textbook "Onomastics" (the term was proposed by A.V. Superanskaya in a slightly different interpretation), the onomastic space is a part of reality marked by proper names [5]. The frequency of use of the metaphorical names in the Chinese language is explained by the richness of the tropes in the language itself: 白鹤滩大坝 - the dam of the "White Crane Shore", 二滩大坝 - the dam of the "Two Shores”, 龙滩大坝 - the dam of “The dragons' Shore”. Among the studied technonyms of the Chinese language, metaphors of various types are used, see Table 3.

Table 3. Types of metaphors of Chinese technonyms.

\begin{tabular}{|c|c|}
\hline types of metaphors & naming units \\
\hline geographical metaphors & HPP Xiangjiaaba 向家坝 “Home-oriented” \\
\hline
\end{tabular}




\begin{tabular}{|c|c|}
\hline chronotope metaphor & $\begin{array}{c}\text { HPP Gezhouba 长江葛洲坝水利枢纽工程 “The Edge of the } \\
\text { Ge Kingdom” }\end{array}$ \\
\hline portrait metaphor & HPP Baichatan 白鹤滩大坝 “White Crane Shore” \\
\hline landscape metaphor & HPP Luntan 龙滩大坝 “Dragon Shore” \\
\hline synesthesia & HPP Manvan 漫湾大坝 “Quiet Bay” \\
\hline technical metaphor & HPP Banciao 板桥水库 “Wooden Bridge” \\
\hline
\end{tabular}

The symbols of natural components are associated with the philosophy of "Feng Shui", which aims at harmonizing the relationship between the nature and human society. T.V. Shmelyova states that it is important to be able to explain the meaning of the onym, to understand the purpose of a certain name for a particular object, to identify a nominative typology in order to assess the degree of originality and expressiveness of the name [5]. Thus, the onomatological analysis of object names allows us to draw some conclusions about the language environment in which these names are formed. Hence, the historical and sociological factor can play a significant role in the formation of the names of certain technical objects, which at first glance seem completely remote and unrelated to the cultural realities of the language environment. "Dry" names of the Soviet era with no trace of artistic style - even they are able to reflect the specific character of the environment in which they were formed.

The analysis of the power facilities names of the Russian-language register revealed that the genus proximum and the differentia specifica of most of the names have a standardized, "non-poetic" character aimed at excluding any misunderstanding. Data analysis of the technonyms in the Russian language are presented in Table 4.

Table 4. Russian technonyms in the sphere of energetics.

\begin{tabular}{|c|c|}
\hline subclasses of technonyms & naming units \\
\hline \multirow{4}{*}{ toponyms } & Perevolotskaya SPP \\
\cline { 2 - 2 } & Buribaevskaya SPP (Baymak SPP) \\
\cline { 2 - 2 } & Irkutsk HPP \\
\cline { 2 - 2 } & Saratovskaya HPP \\
\cline { 2 - 2 } & Bratsk HPP \\
\cline { 2 - 2 } & Volzhskaya HPP \\
\cline { 2 - 2 } & Sayano-Shushenskaya HPP \\
\cline { 2 - 2 } & Zelenograd WPS \\
\hline \multirow{5}{*}{ astronyms } & Yeisk WPS \\
\hline & Perevolotskaya SPP \\
\hline ornithonyms & SPP Solar \\
\cline { 2 - 2 } & SPP Orion Solar \\
\hline \multirow{4}{*}{} & SPP Orion Solar \\
\hline
\end{tabular}

Among the 59 Russian names, 3 astronyms were recorded; 5 names of power facilities of the post-Soviet era formed by the letters of the Greek and Latin alphabets; 1 ornithonym; 49 toponyms. The clear predominance of toponymic technonyms in the Russian language register indicates strictness, clear standardization, stylistically neutral nature of the formation of the power engineering objects names that refer to the realities of the Soviet era, when the naming unit of industrial facilities did not imply any allegory, cf.: SayanoShushenskaya HPP, Donuzlav WPS, Zelenograd WPP etc. Only a few names of modern 
SPP (Crimean SPP, built after 2010) stand out of strictness and restraint of Russian names: thus, zoomorphic metaphors appear, cf.: Osprey Solar (Osprey - Scop bird of prey).

\section{Conclusion}

Thus, when composing the trilingual corpus of the names of renewable energy facilities, 124 technonyms were received. While determining the theoretical foundations of technonyms in the sphere of renewable energy, it was found out that the majority of the studied technonyms are toponymic in nature, i.e. onyms were mostly formed from the names of geographical objects where the power engineering objects were installed. Onomatological analysis also shows that now in Russia and China there is a tendency to call objects using Anglicisms, which indicates a trend towards the internationalization of the technology [7].

Nowadays the branch of renewable energy is dynamically developing, power engineering facilities continuously appear one by one, thus, the onomastic space of languages is continually enriched with new unique names. The study of the peculiarities of the naming units makes it possible to learn more about the cultural realities and unique characteristics of the language environment in which the names of objects are formed, as they are a direct reflection of native speakers' way of thinking in a particular language.

\section{References}

1. A.A. Kohanskaya, Baltic Humanities Magazine, 134, 24 (2013) [in Russian]

2. N.V. Podolskaya, The dictionary of Russian onomastic terminology, 192 (1988) [in Russian]

3. O.I. Kopach, The grammatical structure of the Belarusian language, ways of historical development and current trends, 267 (2007) [in Russian]

4. A.K. Matveev, Onomastic questions, 9 (2005) [in Russian]

5. T.V. Shmeleva, Onomastics, 161 (2013) [in Russian]

6. T.I. Meremkulova, Onomatological analysis of units of the borrowed Gallic formation in modern German literary language, Philological Sciences. Questions of theory and practice, 10, 139 (2017) [in Russian]

7. D.S. Poendaeva, Yu.V. Kobenko, E.S. Riabova, Matec Web Conf. 110 (2017) 